\title{
Attitudes of Primary School Students in UAE Towards Using Digital Story-Telling as a Learning Method in Classroom
}

\author{
Dr. Khaled Younis Alderbashi \\ Associate Professor, Department Chair - Professional Diploma in Teaching, \\ City University College of Ajman - CUCA
}

\begin{abstract}
This study investigated the attitudes of primary school students in UAE towards using digital story-telling as a learning method in classroom. Through the adoption of a descriptive analytical approach, the researcher designed a survey in order to collect primary data. He uploaded the survey to the web through using Google Form. The survey was filled in by 99 female and male primary school students. Thus, the sample involves 99 female and male primary school students. Those sampled students are fifth graders and enrolled in a private primary school in UAE. Data was analysed and processed through SPSS software. Through this program, means and standard deviations are obtained and presented in tables. The researcher concluded several results. For instance, primary school students in UAE show positive attitudes towards using digital storytelling by teachers as a learning method in classroom.. Using this learning method develops students' problem solving, critical thinking, language, and social skills. It increases students' levels of concentration, retention and motivation to learn. However, it doesn't improves students' ability to draft stories nor foster their adjustment within the school environment. The researcher recommends carrying out a study to explore the effectiveness of using the digital storytelling method in UAE kindergartens from the teachers' perspective.
\end{abstract}

Keywords: Attitudes, primary school students, digital storytelling, classroom, learning, UAE

DOI: $10.7176 /$ RHSS/11-10-03

Publication date:May $31^{\text {st }} 2021$

\section{Introduction}

Storytelling refers to the process in which a person (i.e. the storyteller) uses narrative structure, vocalization and mental imagery in the aim of narrating a story to the audience (the listener) (Peck 1989). Many educators and parents use stories in order to teach students or promote a specific value among students. However, during the last decades, the number of technological devices and software have been increasing. Thus, teachers today must integrate technologies in classroom in order to enable students to develop students' $21^{\text {st }}$ century skills. In simple words, they have to integrate technologies with the implementation of the conventional teaching strategies (Ertmer P.A., Ottenbreit-Leftwich, 2010). For instance, when using the storytelling strategy, teachers have to technologies to support the implementation of this strategy. Due to such integration, the term (digital storytelling) emerged.

Digital storytelling refers to the integrating technologies in the process of narrating a story. It involves presenting graphics, images, music, storyteller's voice and sound features (Porter, 2005). It can be defined as the process of narrating a story with using multimedia, like: images and videos. The digital stories must consists from several elements. For instance, it must present the author's point of view. It must include a dramatic question that shall be answered during the end of the story. It must include an emotional content. It must have changes in the voice of the narrator to attract the audience. It must employ music or sound features to attract the audience. It must be simple. That means that the story being narrated must include few information in order to avoid distracting the listeners (Robin, 2008)

There are various types of digital stories. Such types include: 1)-personal stories, 2)- historical stories and 3)- stories for informing the listeners about certain practices or concepts and providing them with knowledge about it. Regarding the personal stories, they shed a light on the personal incidents that occur with one. As for the historical stories, they shed a light on stories related to the past of public and historical figures (Robin, 2008)

Using digital storytelling in classroom improves students' ability to construct narratives by themselves. It improves students' ability to organize their thoughts and ideas and ask questions. It encourages students to express their views and opinions. It attracts students' attention. It improves students' information, visual, technology, and media literacy. (Robin, 2008). It enhances the learners' digital literacy (Maureen et al., 2018). Digital literacy refers to the degree to which one is capable to use information technologies in order learn, carry out entertainment activities or work (Ba et al., 2002). Using digital storytelling in classroom can significantly attract the students and raise the level of students' engagement and motivation to learn. That's because students enjoy listening to stories, especially the digital ones (Smeda et al., 2014)

Using digital storytelling in classroom increases students' engagement in the learning tasks. It increases students' understanding for the content of the curricula (Sadik, 2008). It contributes to promoting good behaviours and healthy habits among students. Such good behaviours and habits include: the ones related to 
eating habits, personal hygiene and safety (Abed Al-Mo'men, 2018). Using digital storytelling in classroom improves students' language skills. It personalizes the learning experience of students. It increases the students' level of concentration (Moradi \& Chen, 2019). It promotes deep learning. It allows students to gain knowledge about others' culture. That is because information about others' cultures can be embedded in some stories (Condy et al., 2012).

Despite that the advantages of using digital storytelling in classroom, Robin (2008) adds that there are challenges associated with such use. For instance, he adds that using such stories can be time consuming. Normann (2011) adds that facing software-related problems may hinder the instructors from using such stories. Such challenges may hinder educators to cover the whole curricula. In this regard, the researcher believes that it's significant to identify how effective it is to use digital storytelling in classroom. That shall contribute to improving primary school education. Therefore, this study investigated the attitudes of primary school students in UAE towards using digital storytelling as a learning method in classroom.

\section{Objective}

This study investigated the attitudes of primary school students in UAE towards using digital storytelling as a learning method in classroom

\section{Question}

This study aimed to answer this question: (What are the attitudes of primary school students in UAE towards using digital storytelling as a learning method in classroom?)

\section{The Study's Significance:}

This is significant due to the points listed below

- This is the first study that investigated the attitudes of primary school students in UAE towards using digital storytelling as a learning method in classroom.

- This study promotes awareness among the developers of children stories about the significance of digital stories in child development in language, behavioural and cognitive areas.

- This study promotes awareness among parents about the about the significance of using digital stories in in order to foster their children development

- This study encourages teachers at kindergartens and primary schools to use digital stories to promote values and teach students.

\section{Limits}

-Temporal limits: This study was carried out during the 2nd semester / academic year (2020/2021)

-Spatial limits: This study targets the UAE primary schools.

-Human limits: This study targets the students enrolled at UAE primary schools.

\section{Definitions:}

\subsection{Theoretical definitions}

- Attitude: It is represented in an evaluative judgment. Through this judgment, one expresses how much he/she prefers a certain person or a certain item (Crano and Prislin, 2006, p.347).

- Digital storytelling: Digital storytelling refers to the integrating technologies in the process of narrating a story. It involves presenting graphics, images, music, storyteller's voice and sound features (Porter, 2005). It can be defined as the process of narrating a story with using multimedia, like: images and videos (Robin, 2008).

\subsection{Operational definitions:}

- Attitudes: They refer to the attitudes of primary school students in UAE towards using digital storytelling as a learning method in classroom

- Digital storytelling: It refers to the process of narrating a story by primary school teachers in UAE in classroom in order to teach students.

\section{Theoretical framework:}

Using digital storytelling in classroom offers students with opportunities to become active learners and enhances students' learning experiences. It turns the academic material connected to reality. It allows students to perceive things from various perspective, because many students shall share their views with colleagues in classroom after narrating the story (Davidson, 2004)

Using digital storytelling in classroom contributes to increasing the degree to which students retain information. That is because the use of attractive visual features shall enable the students to save information in 
the long-term memory. Using digital storytelling in classroom contributes improves students' understanding for difficult material. It increases students' interest in the course and topic being taught. It improves students' social skills and fosters cooperation and collaboration among students, because using digital storytelling offers opportunities for students to work in peers or groups. It can meet the learning needs of several kinds of learners. For instance, it is capable of having the needs of visual and audio learners met, because digital stories include: audio and visual content. It contributes to raising students' emotional intelligence level, because such stories shed a light on social and emotional aspects of life (Robin, 2008)

According to Normann (2011), using digital storytelling in classroom improves students' oral and written skills and digital literacy. It improves students' understanding for the subject and positively affects the learning outcomes. It turns the teaching-learning process into a fun, inspiring, and enjoying process (Normann, 2011). According to Yang and Wu (2012), it improves students' critical thinking skills. The latter skills include the skills of deduction, induction, and interstation. The latter researchers add that using digital storytelling improves students' listening, reading, and writing skills and expand students' vocabulary. They add that such use expand students' grammatical knowledge. They add that such use increases students' self-efficacy. In other words, such use makes students feel capable of mastering skills, understanding difficult material, and getting high scores (Yang and $\mathrm{Wu}, 2012$ )

Using digital storytelling in classroom allows teachers to employ the project-based teaching strategy. It can be effectively used in order to enrich students' knowledge about others' cultures and history. It facilitates the process of choosing the future career by students. It contributes to strengthening the social bonds between students in classroom. That is because it contributes to promoting respect for others regardless of their cultural, socio-economic, racial and ethnic background (Condy et al., 2012).

Using digital storytelling in classroom improves students' problem solving skills. It positively affect the achievement of students and their motivation to learn and obtain knowledge (Hung et al., 2012). It positively affect the writing skills of students and ability to draft stories (Abdollahpour \& Asadzadeh, 2012). According to Thang et al. (2014), it improves students' interactive communication, social, and interpersonal skills. It promotes a sense of social responsibility and enhances the students' visual and technology literacy. It promotes creativity and curiosity. It improves the team work skills of students and promote cooperation. It enables students to improve the skills required in the $21^{\text {st }}$ century labour market, such as problem solving and critical thinking skills. It offers autonomous learning opportunities and improves the learning environment (Thang et al., 2014).

Using digital storytelling in classroom improves student's writing skills (Yamaç, A., \& Ulusoy, 2016). It contributes to promoting empathy with others (Vecchi et al., 2016). It promotes positive behaviours among students. It fosters students' adjustment within the school environment. It allows students to express their own interpretations and perceptions for the world. It offers opportunities to hold discussions. It fosters students' ability to visualize ideas. It fosters interaction and collaboration between students in the same class. It contributes to creating an educational environment that is deemed pleasant and convenient for learning. It improves student's ability to memorize data and recall it when needed (Fokides, 2016).

Using digital storytelling in classroom allows learners to interact with the content. For instance, students can write a comment on the smart board. It allows teachers to offer convenient learning opportunities. For instance, if the teachers are teaching students with attention problems, teachers can employ graphic features to attract students and keep them focused. It allows teachers to update the story to the web in order for students to access it at any time and place in case there is a project related to it. It develops the students' thinking, imagination, analysis and deduction skills. It improves the quality of education (Edyo, 2019)

Using digital storytelling in classroom promotes creativity. It allows students to learn from real life situations (Moradi \& Chen, 2019). It plays a major role in promoting religious values and principles among students (Abdulhameed, 2020). It positively affect the satisfaction of learners with the learning process, because the learning process would be entertaining and enjoyable. It can expand the knowledge of students and develop their skills in using technology (Saritepeci, 2021)

\section{Empirical studies}

Tahriri et al. (2015) explored the impact of digital storytelling on the motivation of EFL learners and their oracy skills. 30 students were selected and divided in a random manner to control and experimental groups. The researcher used a questionnaire to measure motivation and used pre-test and post-test to assess the students' oracy skills (i.e. speaking and listening skills). Analysis of covariance \& multivariate analysis of covariance were carried out. The researchers found that digital storytelling positively affect the motivation of EFL learners and their oracy skills (i.e. speaking and listening skills).

Preradovic et al. (2016) investigated the impact of the use of digital stories on the computer literacy of preschool children in Croatia. He also investigated the impact of such use on the mathematical literacy of those students. Through employing pre-test and post-test, data was gathered from the 41 pre-school children in Croatia. Those students were assigned randomly to control and experimental groups. The experimental group 
was taught through the use of digital stories. However, the conventional teaching method was employed for teaching the other group. The researchers found that the use of digital stories positively affect the computer literacy of pre-school children in Croatia and their mathematical literacy as well.

Sarica and Usluel (2016) investigated the impact of the use of digital stories on the writing skills of students and their visual memory capacity. 59 primary school students were sampled. The sample was divided into control and experimental groups. The groups went through a thirteen-week trial. The experimental group was taught through using the digital storytelling method, whereas the other group wasn't taught through using this method. Pre-test and post-test were designed and used. The researchers found that the use of digital stories significantly improved the writing skills of students and their visual memory capacity.

Maureen et al. (2018) investigated the effectiveness of digital storytelling in improving students' digital literacy in Indonesia. They adopted an experimental approach and carried out an experiment for 3 weeks. 45 children were sampled. The ages of those children are within the range of 5-6 years. The children were divided into three groups (i.e. two experimental groups and a control group). The first experimental group was taught through using the digital storytelling method and the second experimental group was taught through using the conventional storytelling method. The control group was taught through the conventional method. A test was used. The researchers found that the digital storytelling method and the conventional storytelling method have positive impact on improving students' digital literacy in Indonesia.

Altowairqi (2020) investigated how effective it is to use the digital storytelling method in the development of English language speaking and listening skills of second grade students in Jeddah, KSA. Through adopting a semi-experimental approach, he sampled 50 second graders and divided them equally into control group and experimental one. The researcher used digital storytelling to teach the experimental group and the conventional method for teaching the control group. He used pre-test, observation checklist and post-test. The researcher found that the digital storytelling method significantly improves the English language speaking and listening skills

Qaywni (2020) investigated the impact of stories on the promotion of values among fifth graders in Kuwait. Through the adoption of an experimental approach, 42 fifth graders were sampled. The control group involves 20 students and the experimental one consists form 22 students. Pre-test and post-test were used. The researcher reached several results. For instance, using stories can significantly promote loyalty to one's homeland. It can significantly promote integrity, honesty, cooperation, and tolerance. It can significantly promote hygiene-related value. It encourages students to carry out voluntarily works, show kindness to parents, and preserve the public properties. It promotes negative attitudes towards violence.

\section{Methodology}

9.1. Approach

To explore the attitudes of primary school students in UAE towards using digital storytelling as a learning method in classroom, the researcher adopted a descriptive analytical approach

\subsection{Population}

The population involves all the primary school students in UAE. It involves female and male students from grade 1 till grade 5 .

\subsection{Sample}

The researcher designed a survey in order to collect primary data. He uploaded the survey to the web through using Google Form. The survey was filled in by 99 female and male primary school students. Thus, the sample involves 99 female and male primary school students. Those sampled students are fifth graders and enrolled in a private primary school in UAE. Data was analysed and processed through SPSS software. Data about those students are shown below

Table (1): Data about the sampled primary school students

\begin{tabular}{|l|l|l|}
\hline Variable & Category & Frequency \\
\hline \multirow{2}{*}{ Gender } & Female & 61 \\
\cline { 2 - 3 } & Male & 38 \\
\hline
\end{tabular}

$\mathrm{N}=99$ students

\subsection{Instrument}

The researcher designed a survey. He also adopted the five Likert scale that includes five rating categories. The survey includes a cover page. The cover page identifies the name of the researcher and collect data about respondents. The page following the cover page includes the items. The items were drafted based on the articles of: Edyo (2019), Robin (2008), Smeda et al. (2014), Sadik (2008), Abed Al-Mo'men (2018), Moradi \& Chen (2019), Abdollahpour \& Asadzadeh (2012), Maureen et al. (2018), Yang and Wu (2012), Fokides (2016), and 
Thang et al. (2014).

\subsection{Validity}

The researcher passed the initial version of the survey to two faculty members in Jordan and two faculty members in UAE. Those faculty members hold $\mathrm{PhD}$ degree in teaching methods. The researcher asked them to evaluate the survey based on several criteria. Such criteria include: language, relevancy to the study's objective, and clarity. All the experts suggest that survey is clear, free from language-based errors. They suggest that the items are related to the study's objective. However, one of the experts recommended changing the font size of the survey. Another expert recommended adding definitions for the expression (digital storytelling) and (digital literacy) to the survey. Adding this definition shall ensure that all students understand all the items. The final version of the survey is presented in the appendix.

\subsection{Reliability}

The Cronbach alpha value is 0.82 . That proves that the survey used by the researcher is highly reliable. That's because the latter value is greater than 0.70 as it's suggested by Salehi \& Farhang (2019)

\subsection{Analysis Criteria}

For classifying the means, the researcher used the criteria that are shown in the third table below:

Table: (2): The criteria used for the classification of means

\begin{tabular}{|l|l|l|}
\hline Range & Level & Attitude \\
\hline 2.33 or less & Low & Negative \\
\hline $2.34-3.66$ & Moderate & Neutral \\
\hline 3.67 or more & High & Positive \\
\hline
\end{tabular}

*Source: Aljbour (2020)

The five point Likert scale consists from five rating categories. Those categories are shown below

Table (3): The categories and scores of the five point Likert scale

\begin{tabular}{|l|l|}
\hline Category & Score \\
\hline Strongly agree & 5 \\
\hline Agree & 4 \\
\hline Neutral & 3 \\
\hline Disagree & 2 \\
\hline Strongly disagree & 1 \\
\hline
\end{tabular}

*Source: Aljbour (2020)

\section{Results and discussion}

(What are the attitudes of primary school students in UAE towards using digital storytelling as a learning method in classroom?)

Table (4): Attitudes of primary school students in UAE towards using digital storytelling as a learning method in classroom

\begin{tabular}{|l|l|l|l|l|l|}
\hline No. & Statement & Mean & Std. & Attitude & Level \\
\hline & $\begin{array}{l}\text { Using digital storytelling by teacher as a learning method in } \\
\text { classroom }\end{array}$ & & & & \\
\hline 1 & Encourages me to express my views and opinions & 4.42 & 0.53 & Positive & High \\
\hline 2 & Is not time consuming & 1.89 & 0.66 & Negative & Low \\
\hline 3 & Increases my engagement in the teaching-learning process & 4.92 & 0.74 & Positive & High \\
\hline 4 & Increases my motivation to learn & 4.36 & 0.17 & Positive & High \\
\hline 5 & Increases my understanding for the content of the curricula & 4.51 & 0.83 & Positive & High \\
\hline 6 & Encourages me to adopt good behaviours & 4.73 & 0.29 & Positive & High \\
\hline 7 & Increases my level of concentration & 4.85 & 0.37 & Positive & High \\
\hline 8 & Increases my retention for information & 4.69 & 0.46 & Positive & High \\
\hline 9 & Improves my social skills & 4.55 & 0.31 & Positive & High \\
\hline 10 & Improves my critical thinking skills & 4.37 & 0.62 & Positive & High \\
\hline 11 & Improves my problem solving skills & 4.26 & 0.95 & Positive & High \\
\hline 12 & Improves my ability to draft stories & 2.14 & 0.24 & Negative & Low \\
\hline 13 & $\begin{array}{l}\text { Expands my vocabulary, whether the story is narrated in } \\
\text { English or Arabic language }\end{array}$ & 4.32 & 0.77 & Positive & High \\
\hline 14 & Fosters my adjustment within the school environment. & 1.92 & 0.83 & Negative & Low \\
\hline 15 & Offers opportunities to hold discussions & 4.79 & 0.52 & Positive & High \\
\hline
\end{tabular}




\begin{tabular}{|l|l|l|l|l|l|}
\hline No. & Statement & Mean & Std. & Attitude & Level \\
\hline 16 & Promotes values among students & 4.40 & 0.35 & Positive & High \\
\hline 17 & Improves my ability to imagine and visualize ideas & 4.19 & 0.57 & Positive & High \\
\hline 18 & Improves my digital literacy & 3.63 & 0.20 & Neutral & Moderate \\
\hline & Overall & 4.05 & 0.52 & Positive & High \\
\hline
\end{tabular}

*Source: This survey is designed by the researcher based on the articles of Edyo (2019), Robin (2008), Smeda et al. (2014), Sadik (2008), Abed Al-Mo'men (2018), Moradi \& Chen (2019), Abdollahpour \& Asadzadeh (2012), Maureen et al. (2018), Yang and Wu (2012), Fokides (2016). and Thang et al. (2014)

The researcher concluded that primary school students in UAE show positive attitudes towards using the digital storytelling method by teachers in classroom, because the overall mean is 4.05 . That latter result may be attributed to the fact that using the digital storytelling method makes learning enjoyable because children like stories. The researcher found that using the digital storytelling method encourages students to express their opinions and views, because the mean of the first statement is 4.42. This result is in agreement with what's suggested by Robin (2008). It can be attributed to the fact that teacher can ask shed a light on debatable issues in stories in order to let students express themselves.

The researcher concluded that using the digital storytelling method by teachers shall increase the level of students' engagement in the learning process, because the mean of statement 3 is 4.927. This result is in agreement with what's suggested by Sadik (2018). It's because students enjoy engaging in activities that involve the use of ICTs. The researcher concluded that using this learning method the motivation of students to learn, because the mean of statement 4 is 4.36 . This result is in agreement with what's suggested by Smeda et al. (2014). It can be attributed to the fact that students feel motivated to learn through entertaining activities and listening to stories.

The researcher concluded that using the digital storytelling method by teachers increases students' understanding for the content of the curricula, because the mean of statement 5 is 4.51 . This result is in agreement with what's suggested by Sadik (2008). It can be attributed to the fact that stories shed a light on real life examples and connect the material with real life. Thus, that turns complex material into a material that can be easily understood.

The researcher concluded that using the digital storytelling method by teachers encourages students to adopt good behaviours, because the mean of statement 6 is 4.73. This result is in agreement with what's suggested by Abed Al-Mo'men (2018). It can be attributed to the fact that children can be easily influenced by the figures in stories. Thus, teachers can bring to class digital stories that involve good behaviours to influence students in behavioural aspects. The researcher concluded that using the digital storytelling method by teachers increases students' retention for information, because the mean of statement 8 is 4.69. This result is in agreement with what's suggested by Robin (2008). It is because the graphic features in digital stories allow students to save information in their long-term memories.

The researcher concluded that using the digital storytelling method by teachers improves their problem and critical thinking skills, because the means of statement 10 and 11 are 4.37 and 4.26 respectively. This result is consistent with what's added by Thang et al. (2014). It's attributed to the fact that digital stories usually include problems. Thus, teachers usually ask student to think and provide suggested solutions for the problems. That shall offer opportunities to think in a creative manner.

The researcher concluded that using this learning method expands students' vocabulary, because the mean of statement 13 is 4.32. This result is consistent with what's added by Yang and $\mathrm{Wu}$ (2012). That's because stories may introduce new places, countries, dishes, instruments and etc.. The researcher concluded that using this learning method. The researcher concluded that using this learning method offers opportunities to hold discussions, because the mean of statement 15 is 4.79. This result is consistent with what's added by Fokides (2016). It may be attributed to the fact that teachers can hold debates and ask students to provide their views and elaborate them after finishing the digital story.

The researcher concluded that using this learning method promotes values among students, because the mean of statement 16 is 4.40. This result is consistent with what's found by Qaywni (2020). For instance, the latter researcher found that stories contribute to promoting hygiene-related value and other values, like: integrity, honesty, tolerance, kindness to parents and loyalty to homeland. The researcher found that this learning method improves students' ability to imagine and visualize ideas, because the mean of statement 17 is 4.19 . This result is consistent with what's added by Edyo (2019). It may be attributed to the use of audio and visual graphic features in digital stories which enable students to imaging the way in which the stories occurred. Such use allow students to visualize the way in which the characters in the story lived.

However, the researcher found that this learning method is time consuming, because the mean of statement 2 is 1.89 . The same was added by Robin (2008). It may be attributed to the fact that designing a digital story be teachers requires much time. It could be attributed to the fact that narrating a digital story in class requires much time which may hinder teachers from covering the whole curriculum. 
The researcher found that this learning method doesn't enhance students' ability to draft stories, because the mean of statement 12 is 2.14 . This result isn't consistent with what's added by Abdollahpour \& Asadzadeh (2012). That's because drafting stories is a talent rather than a something that can be taught. The researcher found that this learning method doesn't foster students' adjustment within the school environment, because the mean of statement 14 is 1.92 . This result isn't consistent with what's added by Fokides (2016). That's because such adjustment is affected by the personality of teachers rather than their teaching methods. The researcher found that this learning method doesn't enhance students' digital literacy because the mean of statement 18 is 4.63. This result isn't consistent with what's added by Maureen et al. (2018). That's because students don't play a role in designing the digital story when the digital story is brought and narrated by the teacher

\section{Conclusion}

The researcher reached several results. For instance, primary school students in UAE show positive attitudes towards using digital storytelling by teachers as a learning method in classroom. Using the digital storytelling method by teachers in the classrooms of UAE primary schools increases students' engagement in the teachinglearning process and motivation to learn. It promotes better understanding for the content of the curricula and encourages students to adopt good behaviours. It increases students' level of concentration and retention for information. It improves students' problem solving, language, social and critical thinking skills.

However, the researcher found that using the digital storytelling method by teachers in the classrooms of UAE primary schools is time consuming. Thus, using this method in a repetitive manner shall hinder teachers from covering the whole curriculum. The researcher found that using this method shall not improve students' ability to draft stories. The latter result can be attributed to the fact that drafting stories requires being talented rather than being taught. The researcher found that using the digital storytelling method by teachers shall not foster students' adjustment within the school environment. That's because such adjustment is affected by the personality of teachers rather than their teaching methods. The researcher found that using the digital storytelling method by teachers plays a moderate role in improving students' digital literacy. That's because students don't play a role in designing the digital story when the digital story is brought and narrated by the teacher.

\section{Recommendations}

The researcher recommends:

- Providing teachers in UAE with courses and workshops to promote awareness about the benefits of using the digital storytelling method.

- Developing policies by the Ministry of Education in UAE to improve the teachers' teaching competencies. That shall enable teachers to use teaching methods effectively, including the digital storytelling method

- Carrying out a study to explore the effectiveness of using the digital storytelling method in UAE kindergartens from the teachers' perspective

- Carrying out a study to explore the effectiveness of using the digital storytelling method by parents in promote values among children, such as: religious, and citizenship values.

\section{Appendix: The Survey Form}

This appendix presents the survey form. Through this forms, the researcher was capable to gather data.

\section{Survey Form}

Dear participants,

The researcher designed this tool to collect data about a research on the Attitudes of primary school students in UAE towards using digital story-telling as a learning method in classroom. Data you provide will remain confidential and secured to be used for research purpose only.

Dr. Khaled Younis AlDerbashi

Associate professor and head of PDT department at City University College of Ajman.

Please, circle the correct choice

A)- I am $\square$ a male $\square$ a female

Please, use this symbol $(\checkmark)$ to fill in the table below:

Please, read the following definitions before filling in the table:

-Digital storytelling: It can be defined as the process of narrating a story with using multimedia, like: images and videos (Robin, 2008) $)^{1}$. In this survey, this term refers to the narration of a story by your teacher in classroom in order to teach students

\footnotetext{
${ }^{1}$ Robin, B. (2008). Digital storytelling: A powerful technology tool for the 21 st century classroom. Theory into Practice, 47, $220-228$. https://doi.org/10.1080/00405840802153916
} 
- Digital literacy: It refers to the degree to which one is capable to use information technologies in order learn, carry out entertainment activities or work (Ba et al., 2002)2.

Using digital storytelling by teacher as a learning method in classroom

\begin{tabular}{|c|l|l|l|l|l|l|}
\hline No. & Statement & $\begin{array}{l}\text { Strongly } \\
\text { agree }\end{array}$ & Agree & Moderate & Disagree & $\begin{array}{l}\text { Strongly } \\
\text { disagree }\end{array}$ \\
\hline 1 & $\begin{array}{l}\text { Encourages me to express my views and } \\
\text { opinions }\end{array}$ & & & & & \\
\hline 2 & Is not time consuming & & & & & \\
\hline 3 & $\begin{array}{l}\text { Increases my engagement in the teaching- } \\
\text { learning process }\end{array}$ & & & & & \\
\hline 4 & Increases my motivation to learn & & & & & \\
\hline 5 & $\begin{array}{l}\text { Increases my understanding for the content of } \\
\text { the curricula }\end{array}$ & & & & & \\
\hline 6 & Encourages me to adopt good behaviours & & & & & \\
\hline 7 & Increases my level of concentration & & & & & \\
\hline 8 & Increases my retention for information & & & & & \\
\hline 9 & Improves my social skills & & & & & \\
\hline 10 & improves my critical thinking skills & & & & & \\
\hline 11 & Improves my problem solving skills & & & & & \\
\hline 12 & Improves my ability to draft stories & & & & & \\
\hline 13 & $\begin{array}{l}\text { Expands my vocabulary, whether the story is } \\
\text { narrated in English or Arabic language }\end{array}$ & & & & & \\
\hline 14 & $\begin{array}{l}\text { Fosters my adjustment within the school } \\
\text { environment. }\end{array}$ & & & & & \\
\hline 15 & Offers opportunities to hold discussions & & & & & \\
\hline 16 & Promotes values among students & & & & & \\
\hline 17 & $\begin{array}{l}\text { Improves my ability to imagine and visualize } \\
\text { ideas }\end{array}$ & & & & & \\
\hline 18 & Improves my digital literacy & & & & \\
\hline
\end{tabular}

Thank you for taking time to fill in the survey form

\section{References}

\section{References Published in English language:}

Abdollahpour, Z., \& Asadzadeh, N. (2012). The impact of exposure to digital flash stories on Iranian EFL Learners' written reproduction of short stories. Canadian Journal on Scientific and Industrial Research, Vol. 3, p. 40-53

Aljbour, H. (2020). The Training Needs of Educational Leaders in Jordanian Private Universities (An Empirical Study). Journal of Arts, Literature, Humanities and Social Sciences. Vol. 65.p. 415-436, https://doi.org/10.33193/JALHSS.65.2021.449

Ba, H., Tally, W., \& Tsikalas, K. (2002). Investigating children's emerging digital literacies. The Journal of Technology, Learning, and Assessment, 1(4), 5-48

Condy J, Chigona A, Gachago D, Ivala E (2012). Pre-Service Students' Perceptions and Experiences Of Digital Storytelling In Diverse Classrooms. The Turkish Online Journal of Educational Technology. 11(3):278-285

Crano, W. D., \& Prislin, R. (2006). Attitudes and persuasion. Annual Review of Psychology, Vol. 57, p. 345 374, https://doi.org/10.1146/annurev.psych.57.102904.190034

Davidson M. R. (2004). A phenomenological evaluation: using storytelling as a primary teaching method. Nurse education in practice, 4(3), 184-189. https://doi.org/10.1016/S1471-5953(03)00043-X

Ertmer P.A., Ottenbreit-Leftwich A.T. (2010). Teacher technology change: How knowledge, confidence, beliefs and culture intersect. Journal of Research on Technology in Education; Vol. 42:255-284. doi: 10.1080/15391523.2010.10782551

Fokides, E. (2016). Using Digital Storytelling to Help First-Grade Students' Adjustment to School. Contemporary education technology. 7(3), 190-205

Hung, C.-M., Hwang, G.-J., \& Huang, I. (2012). A project-based digital storytelling approach for Improving students' learning motivation, problem-solving competence and learning achievement. Educational Technology \& Society, 15(4), 368-37

\footnotetext{
${ }^{2}$ Ba, H., Tally, W., \& Tsikalas, K. (2002). Investigating children's emerging digital literacies. The Journal of Technology, Learning, and Assessment, 1(4), 5-48
} 
Maureen, I.Y., van der Meij, H. \& de Jong, T. (2018). Supporting Literacy and Digital Literacy Development in Early Childhood Education Using Storytelling Activities. International Journal of Early Childhood. Vol. 50, 371-389. https://doi.org/10.1007/s13158-018-0230-z

Moradi, H., \& Chen, H. (2019). Digital Storytelling in Language Education. Behavioral sciences (Basel, Switzerland), 9(12), 147. https://doi.org/10.3390/bs9120147

Normann, A. (2011). Digital storytelling in second language learning. Masters thesis. Norwegian University of Science and Technology. Faculty of Social Sciences and Technology Management

Peck, J. (1989). Using storytelling to promote language and literacy development. The Reading Teacher, 43(2), $138-141$.

Porter, B. (2005). Digitales: The art of telling digital stories. Denver: Bernajean Porter Consulting.

Preradovic, N.; Lesin, G.; and Boras, D. (2016). Introduction of Digital Storytelling in Preschool Education: a Case Study from Croatia, Digital Education. Issue 30, p. 94-105, https://revistes.ub.edu/index.php/der/article/view/16087

Robin, B. (2008). Digital storytelling: A powerful technology tool for the 21 st century classroom. Theory into Practice, 47, 220-228. https://doi.org/10.1080/00405840802153916

Sadik, A. (2008). Digital storytelling: A meaningful technology-integrated approach for engaged student learning. Educational Technology Research and Development, 56, 487-506.

Sarica, H.; and Usluel, Y. (2016). The effect of digital storytelling on visual memory and writing skills, Computers \& Education, Vol. 94, p. Pages 298-309, https://doi.org/10.1016/j.compedu.2015.11.016.

Smeda, N., Dakich, E. \& Sharda, N. (2014).The effectiveness of digital storytelling in the classrooms: a comprehensive study. Smart Learn. Environ. Vol. 1, https://doi.org/10.1186/s40561-014-0006-3

Tahriri, A., Tous, M. D., \& Movahedfar, S. (2015). The impact of digital storytelling on EFL learners' oracy skills and motivation. International Journal of Applied Linguistics and English Literature, 4(3), p.144-153, doi:10.7575/aiac.ijalel.v.4n.3p.144

Thang, S. M., Lee, Y. S., Najihah, M., Lin, L. K., Noraza, A. Z., \& Kemboja, I. (2014). Enhancing 21st century learning skills via digital storytelling: Voices of Malaysian teachers and undergraduates. The Proceedings of the $13^{\text {th }}$ International Conference on Knowledge-Innovation-Excellence: Synergy in Language Research and Practice. Malaysia. $2^{\text {nd }}-3^{\text {rd }}$ July, 2014

Salehi, M., \& Farhang, A. (2019). On the adequacy of the experimental approach to construct validation: the case of advertising literacy. Heliyon, 5(5) https://doi.org/10.1016/j.heliyon.2019.e01686

Saritepeci, M. (2021). Students' and Parents' Opinions on the Use of Digital Storytelling in Science Education. Tech Know Learn, Vol. 26, p. 193-213, https://doi.org/10.1007/s10758-020-09440-y

Yamaç, A., \& Ulusoy, M. (2016). The effect of digital storytelling in improving the third graders' writing skills. International Electronic Journal of Elementary Education, 9(1), p. 59-86.

Yang, Y-C., \& Wu, W-Ch. (2012). Digital storytelling for enhancing student academic achievement, critical thinking, and learning motivation: A yearlong experimental study. Computers and Education, Vol. 59, p.339-359.

Vecchi, N.; Kenny, A.; and Swift, V.; and Kidd, S. (2016). How digital storytelling is used in mental health: A scoping review. International Journal of Mental Health Nursing, 25(3),183-193 https://doi.org/10.1111/inm.12206

\section{References Published in Arabic language:}

Abdulhameed, A. (2020). The effectiveness of a "proposed program" of educational stories to develop some of the religious values of kindergarten children. Journal of Educational and Psychological Sciences. 4(4), P: 125 - 142, https://doi.org/10.26389/AJSRP.R210719

Abed Al-Mo'men, M. (2018). Employing the digital story in the development of some of the health concepts of kindergarten children. IUG Journal of Educational and Psychology Sciences. 26(3), p 296 -326

Altowairqi, G. (2020). The Effectiveness of Digital Storytelling in Developing Some English Language Communication Skills for Second Graders at Middle Schools in Jeddah. Journal of Educational and Psychological Sciences. 4(12).23-51, https://doi.org/10.26389/AJSRP.G111119

Edyo, L. (2019). Digital education technology and its applications in the educational process (digital stories and computer games samples. Al-Anasa and social sciences Journal. Vol. 05, 28-51. http://dspace.univmsila.dz:8080/xmlui/handle/123456789/19266

Qaywni, L. (2020). The Effect of the Story on the Development of Values of the Fifth Grade Primary students in the State of Kuwait. The Journal of the Faculty of Education-Al-Azhar University. Issue. 185-Part 1, p.173200, http://search.shamaa.org/FullRecord?ID=275852 